\title{
Long Run Relationship between Selected Macroeconomic Indicators and Banking Sector in Pakistan
}

\author{
Javed Pervaiz ${ }^{1}$, Teng Jian-Zhou ${ }^{1} \&$ Junaid Masih $^{2}$ \\ ${ }^{1}$ School of Economics, Northeast Normal University, Changchun, China \\ ${ }^{2}$ School of Economics, Nanjing University of Science \& Technology, Nanjing, Jiangsu, China \\ Correspondence: Teng Jian-Zhou, School of Economics, Northeast Normal University, Changchun, China. \\ E-mail: tengjz270@nenu.edu.cn
}

Received: December 7, 2017

Accepted: December 27, 2017

Online Published: January 5, 2018

doi:10.5539/ijef.v10n2p67

URL: https://doi.org/10.5539/ijef.v10n2p67

\begin{abstract}
The study investigated the long run relationship between selected macroeconomic indicators and banking sector index in Pakistan. The selected macroeconomic indicators are Exports, Industrial Production, CPI, and KIBOR as short-term interest rate, Money Supply (M0), Nominal Exchange Rate between Pakistan and United States of America (USA), Oil Prices and the Interest rate on Pakistan Government bond ten years, as the long-term interest rate. Monthly time series was used from January 2009 to August 2015. The study applied Augmented Dickey-Fuller test to determine the stationarity levels for the selected macroeconomic indicators and banking sector index, Phillips-Perron test to validate the results of Augmented Dickey-Fuller test, a bound testing technique in ARDL model to investigate the long run relationship between selected macroeconomic variables and banking sector index. Results suggested the presence of a long-run relationship between macroeconomic variables exchange rate, inflation, oil price and banking sector index in Pakistan. Results of Granger causality test suggested unidirectional causality running from macroeconomic variables KIBOR and oil prices to banking sector index in Pakistan. Further, unidirectional causality was found running from banking sector index to government bond in Pakistan.
\end{abstract}

Keywords: ARDL, Phillips-Perron, ADF, Granger causality, CPI, KIBOR

\section{Introduction}

The body The Long run co-movement and the Causal relationship between different macroeconomic variables and equity returns had been a center of discussion for some recent time. The stock returns in any economy are considered to be susceptible to the changes in macroeconomic variables in the economy (Hasan \& Javed, 2009). Owing to this fact, the examination of long run co-movement, short term relationship and causal relationship between macroeconomic variables and stock returns in Pakistan has become significant. This study used stock prices for banks listed at Karachi Stock Exchange (KSE). The study examined the long run co-movement, short run relationship and causal relationship between selected macroeconomic variables and stock returns for banks listed at KSE.

The stock market in Pakistan is volatile in nature (Attari \& Safdar, 2013). In volatile stock markets, both the investors as well as the regulators need to assess the situation by using different statistical tools to manage and minimize the risk associated with the investment in the stock market (Ali, Rehman, Yilmaz, Khan, \& Afzal, 2010). The study of long-run equilibrium, short run relationship and causal relationship between macroeconomic variables and banking sector performance in Pakistan will help to assess the association and linkage among them. These examined association and ties could be used to minimize the risk in future by the investors.

As per the ratings of International Monetary Fund (IMF), Pakistan has been categorized under the status of developing country (IMF, 2014). The study of linkage between Stock prices and macroeconomic variables is being carried out in developed, developing and underdeveloped countries due to the significance of this topic. Different researchers in developing countries have conducted similar research on examination of macroeconomic variables and stock returns and an illustrative list of such studies includes Erdem, Arslan, and Erdem (2005), Granger, Huang, and Yang (2000), Ibrahim and Yusoff (2001), Kutty (2010), Phylaktis and Ravazzolo (2005), Pilinkus (2009), Singh, Mehta, and Varsha (2011) and Wongbangpo and Sharma (2002). These studies conducted 
in developing countries used macroeconomic variables such as Money Supply M1, Exchange Rate, Inflation, Interest Rate, Industrial Production Index and Exports Volume. The macroeconomic variables used in this study are Stock prices for listed banks at KSE, Consumer Price Index (CPI) as measure of inflation, Exchange rate, Oil Prices, Exports Volume, Pakistan Government Bond Yield 10 year rate as a proxy for long-term interest rate, Karachi Interbank Offer Rate (KIBOR) as a proxy for short-term interest rate, Industrial Production, Money Supply (M0) and Whole Price Index (WPI) as a proxy for inflation at Whole Sale market.

After knowing the importance of all variables stated above the research identifying the association between the banking sector and macroeconomic indicators in Pakistan which would help investors to predict the banking industry performance by observing the macroeconomic indicator's trend in Pakistan. The research will also assist the investors regarding the significant macroeconomic indicators responsible for changes in banking sector index performance and by using such macroeconomic indicators the investors will be in a position to formulate their investment plan in the banking industry and portfolio investments containing banking sector as well. The research also identify the long-run associated macroeconomic variables with banking sector index will help foreign investors to forecast the banking sector index and will enhance foreign investment in the equity market.

\section{Literature Review}

The Method section describes in detail how the study was conducted, including conceptual and operational definitions of the variables used in the study, Different types of studies will rely on different methodologies; One of the previous studies conducted by Husain and Mahmood (2001) investigated the causal relationship between the stock market and economic growth in Pakistan. Farooq, Keung, and Kazmi (2004) conducted research to find out the existence of the causal relationship between the stock exchange prices and Exchange rate in Pakistan, and for this analysis, the stock market prices were taken from KSE. Fazal Husain (2006) conducted the study on the causal relationship between the Stock prices and Real sector in Pakistan. A survey carried out by Akmal (2007) was focused towards the investigation of the long run and short run relationship between inflation and stock prices in Pakistan. Another study was conducted by Shahbaz, Ahmed, and Ali (2008) in which they investigated short run causality relationship between Stock market development and Economic Growth in Pakistan.

Hasan and Javed (2009) conducted the study on the empirical causal relationship between different monetary variables in Pakistan and Equity market returns in Pakistan by utilizing the KSE equity returns in the study. Sohail and Hussain (2009) conducted a study in which they evaluated the long run and short run relationship between the macroeconomic variables and stock prices in Pakistan, and for this, they took the stock prices from LSE. There are different ratios which can be used to evaluate the performance of banks. The net interest margin, spread ratio, and overhead efficiency are some of the ratios which are commonly utilized in research to measure the performance of banks (Saunders, 2011). Spread ratio can be defined as the difference between the average return on earning assets and the average cost of interest-bearing liabilities (Saunders, 2011).

One of the research analyzed different determinants of interest rate spread of commercial banks in Pakistan by employing linear regression technique (Khan \& Khan, 2010). Ali, Rehman, Yilmaz, Khan, and Afzal (2010) conducted their study to investigate the causal relationship between different macroeconomic indicators and stock exchange prices in Pakistan by using the stock returns in KSE. Saeed and Akhter (2012) conducted their research on the impact of some selected macroeconomic factors on banking sector of Pakistan. Infection ratio is ratio of nonperforming loans against the total loan portfolio of the bank (International Monetary Fund, 2010). Thus, Infection ratio can serve as the measure of nonperforming loans for banks. One of the studies related investigated the economic determinates of nonperforming loans from Pakistani bankers perception (Farhan, Sattar, Chaudhry, \& Khalil, 2012).

Haider (2013) conducted the study to examine the relationship between selected macroeconomic variables and stock movement in KSE. A study conducted by Khan (2014) explored the impact of different selected macroeconomic variables on KSE-100 index in Pakistan. Mahmood, Waheed, and Khalid (2014) conducted research to examine the long run relationship between selected macroeconomic variables and banking crisis in Pakistan. Rasool and Hussain (2014) explored the impact of different selected macroeconomic indicators on stock prices at LSE. The selected macroeconomic indicators were exchange rate, foreign exchange reserves, Industrial production index, Interest rate, Imports, Money Supply, Wholesale price index and exports. The study investigated long run relationship as well as causality between selected macroeconomic indicators and stock prices at LSE.

Husain and Mahmood (2001) applied Johansen's Cointegration test to explore the long run association between the stock market and economy of Pakistan and further used Error Correction Model (ECM) to identify the causal relation between stock market and economy of Pakistan. Another study conducted by Farooq, Keung and Kazmi 
(2004) employed Johansen's Cointegration technique to investigate Long term relationship between Stock prices and exchange rate in Pakistan. Fazal Husain (2006) applied Johansen's Cointegration test to spot Long term relationship between Stock prices and real sector in Pakistan. The study further deployed Vector Error Correction Model (VECM) to identify causal relation in a Short run between Stock prices and real sector in Pakistan. A study conducted by Akmal (2007) utilized ARDL approach and Co-integration technique to examine the long-run relationship between inflation and stock prices in Pakistan. The study further used ECM approach to investigate the short run relationship between inflation and stock prices in Pakistan. Shahbaz, Ahmed and Ali (2008) applied Johansen's Cointegration test to identify the long-run association between Stock market development and economic growth in Pakistan. Further, they used Granger Causality test to determine Causal relationship and ARDL approach to identify short run dynamics between Stock market development and economic growth in Pakistan.

Kim (2003) conducted a study on U.S stock market in which long-term equilibrium relationship between different macroeconomic variables and Stock returns in U.S market were investigated. Beltratti and Morana (2006) conducted research in U.S stock market focused towards the examination of the relationship between different macroeconomic variables and stock market volatility. Gan, Lee, Yong, and Zhang (2006) conducted research on the relationship between different macroeconomic variables and Stock market returns in New Zealand. Another study was conducted on U.S stock market by Ratanapakorn and Sharma (2007) in which they examined long term, and short term relationship between different macroeconomic variables and Stock returns in U.S. Humpe and Macmillan (2009) conducted research on whether different macroeconomic variables influence the stock prices in developed countries like U.S and Japan. Monir, Saiti, and Masih (2014) performed research to examine causality between selected macroeconomic variables and stock market index in Malaysia. The study also examined the dynamic relationship between selected macroeconomic variables and stock market index in Malaysia.

A study conducted by Kim (2003) suggested that stock returns in U.S are positively associated with the industrial production but is negatively related to the exchange rate, interest rate, and inflation in the long run. Gan, Lee, Yong, and Zhang (2006) found that macroeconomic variables interest rate, money supply, and real GDP does Granger cause stock returns in New Zealand and the stock market in New Zealand is not a leading indicator for changes in selected macroeconomic variables in the study. A study conducted by Ratanapakorn and Sharma (2007) concluded that stock returns in U.S negatively relates to long-term interest rate and positively relates to money supply, inflation, exchange rate, industrial production, and short-term interest rate in the long run. All the selected variables in the study Granger causes the stock returns in the long run but not in short run.

A study conducted by Humpe and Macmillan (2009) found in their research that Stock returns in U.S are positively integrated with industrial production while negatively integrated with CPI and long-term interest rate. For Japanese Stock market, the study found that stock returns in Japan are positively cointegrated with industrial production and negatively integrated with the money supply. The results of the survey conducted by Monir, Saiti, and Masih (2014) suggested that macroeconomic variables short-term interest rate, government bond and Kuala Lumpur Composite Index are exogenous variables as per ECM technique used in the study.Ibrahim and Yusoff (2001) conducted the study analyzing the dynamic relations between the various macroeconomic variables and stock prices in Malaysian Stock Market. Wongbangpo and Sharma (2002) conducted a study in which they investigated the role of selected macroeconomic variables on the stock prices in five associations of Southeast Asian Nations (ASEAN) countries. A study conducted by Panetta (2002) identified the macroeconomic factors influencing the Italian equity market and the relation stability of the defined variables with securities returns in Italy. A study conducted by Erdem, Arslan, and Erdem (2005) investigated the effects of different selected macroeconomic variables on the Istanbul stock exchange indexes. Phylaktis and Ravazzolo (2005) conducted a study in which they investigated the long run and short run dynamics between stock prices and exchange rate in five Pacific basin countries. Gay (2008) examined the effect of selected macroeconomic variables on stock market returns in Brazil, Russia, India and China. The study selected exchange rate and oil price for Brazil, Russia, India and China. Pilinkus and Boguslauskas (2009) conducted a study to analyze the relationship of cause and effect between selected macroeconomic variables and Lithuanian Stock market index.

Kutty (2010) in his study investigated the relationship between stock prices and exchange rates in Mexico. Singh, Mehta, and Varsha (2011) conducted a study examining the relationship of cause and effect between different selected macroeconomic variables and share prices in Taiwan Stock market. Pal and Mittal (2011) did research on exploring a long run relationship between selected macroeconomic indicators and Indian capital market. The macroeconomic indicators included in the study were interest rates, inflation rate, exchange rates and gross domestic savings. The study also investigated short run dynamics between selected macroeconomic indicators 
and Indian capital market. A study conducted by Tandon and Malhotra (2012) was focused towards the examination of relationship and causality between selected macroeconomic variables and a stock market in India. Another study investigated the impact of nonperforming loans on systemic risk in the banking sector by formulating a comparative study of Serbia and countries in transition (Vuković \& Domazet, 2013). Research conducted by Ray (2012) focused on the causal relationship between different selected macroeconomic variables and stock price behavior in India. A study carried out by Al-Majali and Al-Assaf (2014) explored long run and short run relationship between selected macroeconomic variables and stock prices in Jordan.

The results of the study conducted by Tandon and Malhotra (2012) suggested that Stock prices in India have the positive relation with Broad Money M3 and Industrial Production Index while stock prices have the negative relationship with Exchange Rate and the Inflation rate in India. Research conducted by Ray (2012) focused on the causal relationship between different selected macroeconomic variables and stock price behavior in India. The results of the study by Ray (2012) provided evidence that there is no existence of the causal relationship between stock prices, interest rate and index of industrial production. The results of the study conducted by Al-Majali and Al-Assaf (2014) suggested that there is an existence of the negative long-run relationship between CPI and stock prices in Jordan. The study also found that there is a positive relationship between real GDP and stock prices in Jordan in the long run.

Ali M. B. (2011) conducted his study to examine the causal relationship between different selected macroeconomic variables and stock prices in Dhaka Stock Exchange. Mireku, Sarkodie, and Poku (2013) conducted the study to examine the prevalence of long run and a short term association between the selected macroeconomic variables and stock prices in Ghana. Another study in Ghana conducted by Issahaku, Ustarz and Domanban (2013) explored long run the association, short run association and causality between selected macroeconomic variables and stock prices. Babatunde, Adenikinju, and Adenikinju (2013) investigated the interactive relationship prevailing between the oil prices shocks and the stock market of Nigeria.

Ali and Akujuobi (2014) investigated the relationship between stock market returns and selected macroeconomic variables in Nigeria. The study selected exchange rates, money supply, and loan to the private sector and net foreign assets as macroeconomic variables. Both short run and long run relationship between stock market returns and selected macroeconomic variables in Nigeria were investigated.

A study conducted by Mireku, Sarkodie, and Poku (2013) utilized Cointegration test to examine long run association and VECM technique to identify a short run relationship between selected macroeconomic variables and the stock market in Ghana. Issahaku, Ustarz, and Domanban (2013) applied Johansen's Cointegration test to identify long run association and also used VECM approach to identify a short run relationship between selected macroeconomic variables and the stock market in Ghana. The study further employed Granger Causality test to examine the existence of causality between selected macroeconomic variables and the stock market in Ghana. Babatunde, Adenikinju, and Adenikinju (2013) employed multivariate VAR regression technique to investigate the relationship between oil price shocks and the stock market in Nigeria. A study conducted by Ogunmuyiwa and Okuneye (2014) utilized OLS regression technique to identify the impact of macroeconomic indicators inflation and exchange rate on Nigerian stock exchange index. Ali and Akujuobi (2014) used Augmented Dickey-Fuller (ADF) test to test the stationarity of the stock market returns and selected macroeconomic variables in the study. Engle and Granger Co integration test was employed in the study to examine if there prevails long run relationship between stock market returns and selected macroeconomic variables in Nigeria.

A study conducted by Quartey and Gaddah (2007) indicated that real income, gross domestic savings, domestic credit to the private sector and exchange rate are associated in the long run with the stock market in Ghana. The study also found a negative relationship between Treasury bill rate and the stock market in Ghana. Adam and Tweneboah (2008) found in their study that the selected macroeconomic variables have the significant relationship with the stock market in Ghana. The study of Maku and Atanda (2009) provided the conclusion that there is the presence of long-term relationship between selected macroeconomic variables and the stock market in Nigeria. The study also found that the selected macroeconomic variables do exhort significant short-term shocks on the stock market in Nigeria.

Mireku, Sarkodie, and Poku (2013) concluded in their research that CPI, Interest rate and exchange rate does have the significant long run relationship with stock prices in Ghana. The study concluded that CPI has a positive long run association while Interest rate and Exchange rate have the negative long-run association with stock prices in Ghana. Issahaku, Ustarz, and Domanban (2013) concluded in their study that there is an existence of the long-term relationship between inflation, money supply, FDI and stock returns in Ghana. The study also found that macroeconomic variables inflation, money supply, and interest rate are associated with stock returns 
in Ghana in short run. Babatunde, Adenikinju, and Adenikinju (2013) found in their study that stock market returns in Nigeria do exhibit insignificant positive reply to oil price changes. The results obtained from the study of Ogunmuyiwa and Okuneye (2014) suggested that inflation and exchange rate both macroeconomic variables are crucial in identifying the stock movement in Nigerian stock exchange market. Ali and Akujuobi (2014) results suggested that the stock market returns and selected macroeconomic variables are stationary. The results suggested that there prevails long run relationship between stock market returns and selected macroeconomic variables in Nigeria. Study found inverse relationship between exchange rate and stock market return in short run while a positive relationship between loan to private sector and stock market return in short run.

This extensive literature review provided the study with a research gap. Extensive study related to stocks in Pakistan depicted that macroeconomic indicators, export and interest rate on Pakistan government bond yield ten years has rarely been included in past studies to investigate their relationship with stock return. Further, few studies have investigated the stock return in the banking sector in Pakistan providing an opportunity to further investigate the stock returns in the banking sector. Thus, this study included exports and interest on Pakistan government bond yield ten years as identified macroeconomic indicators in research gap. Du to less study of banking sector stock returns in Pakistan, this study filled a significant gap in understating the relationship and causality between different selected macroeconomic indicators and stock returns in Pakistan.

\section{Research Methodology}

\subsection{Long Run Association}

It is both Statistical association refers to relationship or correlation between two variables or more variables (Galderisi, 2015). Association in statistics can be in short run and long run. There are different tools which are used to identify short run and a long run association between variables. If the selected time series are stationary at the same level, then Johansen's Co integration technique is applied to investigate a long run association between the selected time series.

Johansen's Cointegration technique was proposed by Johansen and Juselius (1990) for long run association investigation. If the selected time series are stationary at the different level, then autoregressive distributed lag (ARDL) technique can be applied to investigate the long run association between the selected time series (Vita \& Abbott, 2004). ARDL technique was initially proposed by Pesaran and Shin (1999) and then later on revised by Pesaran, Shin, and Smith (2001) for long run association investigation. This study used ARDL technique to investigate the long run association between selected time series. The usage of ARDL technique formulated base for the application of Granger's causality test. The presence of long run association between selected time series increased the chances of causality presence also either unidirectional or bidirectional or both.

\subsection{Unidirectional and Bidirectional Causality}

Appropriate identification Finding out a causal link between two or more variables is not an easy task as identification of real causality is a challenging task at any level. There are different techniques which could be employed to test the causation between different selected variables in any study. There are different reasons due to which different kinds of causal examination can be employed from a statistical point of view (Denzin \& Giardina, 2011). Grangers Causality is one of these deferrer causal techniques in statistics which is used to examine the causal relationship between two or more variables (Florin, 2010).

Bidirectional Causality is simply the quantitative technique which is used to examine the existence of the causal relationship between two or more variables under study. One is the dependent variable while the rest are the independent variables. Grangers Causality technique helps to identify the unidirectional causality as well as bi-directional causality between the selected variables in the study. The unidirectional causality is also known as One-Way Causality. Under unidirectional causality, the direction of the causal link is in one way. For instance, there are two variables in the study known as Variable A and Variable B. Under unidirectional causal link, either Variable A will be the cause for effect in Variable B or Variable B will be the cause for effect in variable A (Macy, 2010).

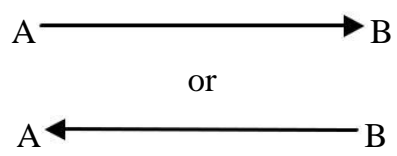

Bidirectional Causality is also known as Two-Way Causality. Under bidirectional causality, the direction of the causal link between variables in the study is in two ways. For instance, if there are two variables taken in the study and them are variable A and variable B. Consider on employing Grangers Causality test, the results suggest 
that their exists bidirectional causal link between variable A and B. This means that Variable A will be cause for effect in Variable B and Variable B in return will be the cause for effect in Variable A. So, in such circumstances both of the selected variables in study will be causing effect in each other.

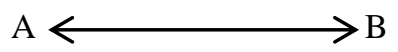

\subsection{Granger's Causality}

Describe the procedures Granger's Causality technique in statistics is used to examine Causality link between any two or more variables. The Granger's Causality link may suggest no linkage between variables, the unidirectional linkage between variables or bidirectional linkage between variables. By using Granger's Causality test, this study tested whether banking sector in Pakistan is a leading economic indicator or a lagging economic indicator on each selected macroeconomic variable in the study.

Granger's Causality technique was suggested by Granger (1969) to test causality linkage between two or more variables in a quantitative manner. Granger formalized the concept which was originally given by (Wiener, 1956). Wiener basically defined the concept of Causality in such a manner that if one can predict correctly the values for any $\mathrm{Y}$ times series by using values of $\mathrm{X}$ time series instead of using only previous information of $\mathrm{Y}$ time series then the $\mathrm{X}$ time series is known as causal time series for $\mathrm{Y}$ time series (Florin, 2010). Under this definition and scenario, the time series of $\mathrm{X}$ is causing effect or change in values of $\mathrm{Y}$ time series. This basic concept of causality was later on then converted into a formula by Granger which is now known as Granger's Causality technique. In the original notation, Granger's causality is a bivariate concept. The basic Granger's Causality technique is based upon two-time series having the temporal ordering. The main idea behind this concept is that the cause in any causal link must always precede the effect as a cause is a reason for the effect. Granger's Causality technique will statistically test temporal causation between two-time series. The causal relationship testing between time series is temporal causation, and it is not necessary that the causal linkage implies the existence of true causality between time series (Florin, 2010).

\section{Results}

In the Results The study initially employed descriptive test on banking index and selected macroeconomic variables to identify the descriptive statistics of the time series included in the study. The descriptive statistics helped to interpret the performance of the banking index and selected macroeconomic variables in a summarized manner. The results of descriptive test employed on the time series in study are:

Table 1. Descriptive statistics for indicators

\begin{tabular}{lccccccc}
\hline Variables & Obs & Mean & Median & Std. Dev. & Skewness & Kurtosis & Jarque-Bera (Prob.) \\
\hline Ind & 78 & 999.6 & 1,001 & 7.42 & -5.26 & 39.45 & 0.00 \\
Bond & 78 & 12.83 & 12.96 & 1.02 & 0.51 & 4.07 & 0.02 \\
Exrus & 78 & 87.75 & 85.95 & 11.06 & -0.44 & 3.03 & 0.28 \\
Exp & 78 & 166,624 & 175,823 & 40,661 & 0.01 & 2.21 & 0.36 \\
Inf & 78 & 12.09 & 11.21 & 4.53 & 1.14 & 3.98 & 0.00 \\
IP & 78 & $2,716,826,812$ & $2,635,372,063$ & $275,232,923$ & 0.59 & -0.89 & 0.02 \\
KIBOR & 78 & 10.83 & 11.33 & 1.45 & -0.17 & 1.67 & 0.04 \\
Money & 78 & $2,013,879$ & $1,958,605$ & 475,734 & 0.27 & 1.85 & 0.07 \\
Oil & 78 & 89.78 & 94.00 & 18.49 & -0.60 & 4.06 & 0.01 \\
\hline
\end{tabular}

The base value for banking index selected in this study was 1,000 points. The descriptive results suggest that the banking index during January 2008 to August 2014 stood at 999.6 points on average. This suggests that overall stock performance of banking sector during the selected period of study remained close to 1,000 points on average. The median value of banking index suggested that most of the time, the banking index closed at 1,001 points. 


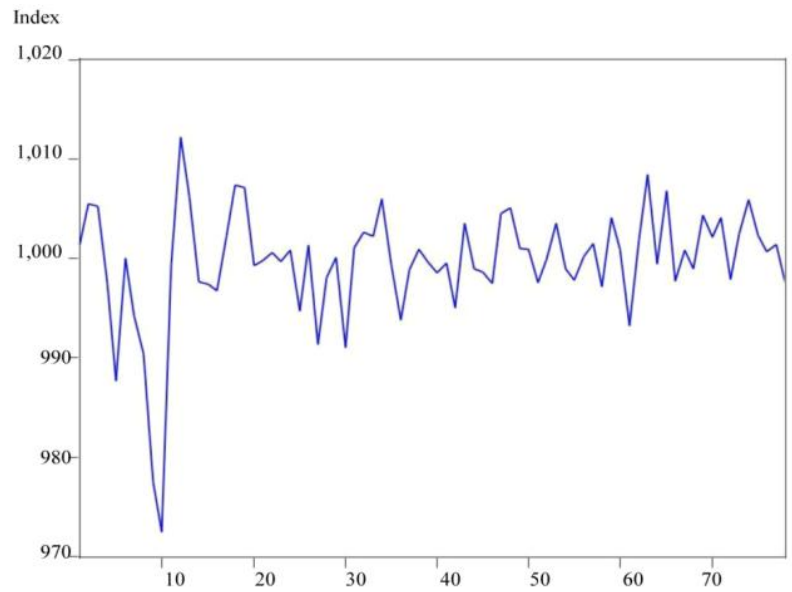

Figure 1. Movement of banking sector index

Figure 1 depicts the graphical movement of banking index from January 2009 to August 2015 in Pakistan. The sharp fall in banking index value was observed at the end of 2009. One of the most significant reasons for the fall of banking index at the end of 2009 was the global financial crisis. Due to global financial crisis, the non-performing loans around the globe reduced significantly, and this impacted negatively towards the performance of banking sector at the global level (United Nations, 2009).

The study employed ADF test to identify the level of integration between the data. The investigation of the level of integration in the data helps to identify the stationarity of the data (Nkusu, 2011). The data being used in the study for analysis should be stationary in nature as this is one of the basic assumptions of time series data to be linear (Palit \& Popovic, 2006). Without stationary data in time series research, the results produced by linear models will be spurious or misleading (Downward \& Dawson, 2002). The study also employed Phillips-Perron test (PP) to validate and confirm the results obtained from ADF test. The ADF and PP test are applied to investigate unit root in the data. If there is a presence of Unit root in the data, then that data is termed as non-stationary data while in the absence of unit root in data, it is termed as stationary data. The null and alternative hypotheses for unit root tests are as follows: H0: There is the presence of unit root in time series.

H1: There is no presence of unit root in time series.

To declare the time series stationary, it is required that the null hypothesis of unit root test is statistically not accepted (Kuijs \& Borghijs, 2004). If the time series selected in the study are integrated of same order, then the series can be tested for the prevalence of cointegration between them (Wang \& Fasano-Filho, 2002). The application of ADF test and PP test identified that all of the selected macroeconomic series and banking indexes are stationary between I (0) and I (1). This implies that the selected macroeconomic series and banking index are integrated at different levels like I (0) and I (1). The results of ADF test applied on the variables are shown on the following page:

Table 2. Results for ADF unit root test

\begin{tabular}{llcccc}
\hline \multirow{2}{*}{ Variables } & \multicolumn{3}{c}{ ADF with Intercept } & \multicolumn{2}{c}{ ADF with Intercept and trend } \\
\cline { 2 - 6 } & \multicolumn{3}{c}{ Test Statistics } & \multicolumn{2}{c}{ Test Statistics } \\
\cline { 2 - 6 } At Level & At 1st Difference & At 2nd Difference & At Level & At 1st Difference \\
\hline Index & $-5.60^{* * *}$ & - & - & $-5.84^{* * *}$ & - \\
Bond & $-3.77^{* * *}$ & - & - & $-4.04 * *$ & $-7.93^{* * *}$ \\
Exchange Rate(U.S) & $-2.86^{*}$ & $-6.56^{* * *}$ & - & -1.89 & $-6.87 * * *$ \\
Inflation & -1.59 & $-10.13^{* * *}$ & - & -2.72 & -10.16 \\
Industrial Production & -0.98 & $-5.82^{* * *}$ & - & $-3.73^{* *}$ & $-5.84^{* * *}$ \\
KIBOR & 1.25 & $-2.78^{*}$ & $-9.57^{* * *}$ & -2.21 & $-7.57^{* * *}$ \\
Money Supply (M0) & -2.04 & $-11.24^{* * *}$ & - & -2.84 & $-11.36^{* * *}$ \\
Oil Prices & 0.49 & $-11.35^{* * *}$ & - & $-3.80^{* *}$ & $-11.35^{* * *}$ \\
\hline
\end{tabular}

Note. *Variably is significant at $.10(10 \%)$ significance level; **Variable is significant at $.05(5 \%)$ significance level; ***Variable is significant at .01(1\%) significance level. 
The ADF test was applied once with the presence of intercept and once with the presence of both intercept and trend in time series. The results of ADF test suggests that banking index and government bond are stationary with the intercept at the level of $10 \%, 5 \%$, and $1 \%$ significance level. The exchange rate with U.S is stationary with the intercept at the level against 10\% significance level while oil prices are stationary with the intercept at the level of $10 \%$ and $5 \%$ significance level. Other variables which include exports, inflation, KIBOR and money supply all are stationary with the intercept at 1 st difference against $10 \%, 5 \%$, and $1 \%$ significance level. The industrial production is stationary with the intercept at 1st difference against $10 \%$ significance level while it is stationary with the intercept at 2nd difference against 10\%,5\%, and $1 \%$ significance level.

The ADF test was also employed with the presence of intercept and constant both. The results depict that banking index is stationary with intercept and constant at the level against $10 \%, 5 \%$, and $1 \%$ significance level. Variables including government bond, inflation, and money supply are stationary with intercept and constant at the level against $10 \%$ and 5\% significance level while they are stationary with intercept and constant at 1st difference against $10 \%, 5 \%$ and $1 \%$ significance level. Other variables which include exchange rate with U.S, exports, industrial production, KIBOR, and oil prices are stationary with intercept and constant at 1st difference against $10 \%, 5 \%$ and $1 \%$ significance level. To verify the results obtained from ADF test, the study employed PP test to investigate the stationarity of the time series taken in the study. The results of PP test are as follows:

Table 3. Results for Phillips-Perron test

\begin{tabular}{lcccc}
\hline \multirow{2}{*}{ Variables } & \multicolumn{2}{c}{ PP with Constant } & \multicolumn{2}{c}{ PP with Constant and trend } \\
\cline { 2 - 5 } & \multicolumn{2}{c}{ Test Statistics } & \multicolumn{2}{c}{ Test Statistics } \\
\cline { 2 - 5 } & At Level & At 1st Difference & At Level & At 1st Difference \\
\hline Index & $-5.38^{* * *}$ & - & $-5.37 * * *$ & - \\
Bond & $-3.16^{* *}$ & $-7.95^{* * *}$ & $-3.28^{*}$ & $-7.93^{* * *}$ \\
Exchange Rate(U.S) & -2.50 & $-6.76^{* * *}$ & -2.23 & $-6.99^{* * *}$ \\
Exports & -2.33 & $-14.96^{* * *}$ & $-5.34^{* * *}$ & - \\
Inflation & -1.66 & $-5.91^{* * *}$ & $-3.22^{*}$ & $-5.94^{* * *}$ \\
Industrial Production & $-3.09^{* *}$ & $-8.09^{* * *}$ & $-3.57^{* *}$ & $-8.07^{* * *}$ \\
KIBOR & -1.84 & $-11.51^{* * *}$ & -2.67 & $-11.87^{* * * *}$ \\
Money Supply (M0) & 0.25 & $-11.81^{* * *}$ & $-3.69^{* *}$ & $-11.94 * * *$ \\
Oil Prices & $-2.70^{*}$ & $-6.94 * * *$ & -2.90 & $-6.90^{* * *}$ \\
\hline
\end{tabular}

Note. *Variably is significant at $.10(10 \%)$ significance level; **Variable is significant at $.05(5 \%)$ significance level; ***Variable is significant at .01(1\%) significance level.

The application of ADF test and PP test identified that all of the selected macroeconomic series and banking indexes are stationary between $\mathrm{I}(0)$ and $\mathrm{I}(1)$. This implies that the selected Macroeconomic series and banking index are integrated at different levels like $\mathrm{I}(0)$ and $\mathrm{I}(1)$. The result of PP test suggests that banking index is stationary with the intercept at the level against $10 \%, 5 \%$, and $1 \%$ significance level. The government bond and industrial production are stationary with the intercept at level against 10\% and 5\% significance level while these two variables are stationary with intercept at 1 st difference against $10 \%, 5 \%$ and $1 \%$ significance level. Oil prices are stationary with intercept at level against $10 \%$ while it is stationary with intercept at 1 st difference against $10 \%, 5 \%$ and $1 \%$ significance level. All other variables exchange rate with U.S, exports, inflation, KIBOR and money supply are stationary with intercept at 1 st difference against $10 \%, 5 \%$ and $1 \%$ significance level.

The PP test was also conducted with the presence of intercept and constant both. The result provides evidence that banking index and exports are stationary at level with intercept and constant against 10\%, 5\% and 1\% significance level. Industrial production and money supply are stationary at level with intercept and constant against $10 \%$ and 5\% significance level while they are stationary at 1st difference against $10 \%, 5 \%$ and $1 \%$ significance level. The government bond is stationary with intercept and constant at level against $10 \%$ significance level while they are stationary with intercept and constant at 1 st difference against 10\%, 5\% and $1 \%$ significance level. Variables KIBOR, exchange rate with U.S and oil prices are stationary with intercept and constant at 1 st difference against $10 \%, 5 \%$ and $1 \%$ significance level.

All the variables are integrated of order $\mathrm{I}(0)$ or $\mathrm{I}(1)$ as per the stationarity tests except industrial production. The variable industrial production is stationary at $2 \mathrm{nd}$ difference with intercept as per ADF test while it is stationary at 1st difference with intercept and constant as per ADF test. The PP test justified it by suggesting that industrial production is stationary at 1 st the difference with intercept and constant. Thus, it is possible to use industrial 
production in ARDL approach by including both intercept and constant in it. Before investigating the long run association between banking index and selected macroeconomic variables, the study identified the optimum lag order by employing lag selection criterion. The results of lag selection criterion are given in the following table:

Table 4. Lag selection criterion result

\begin{tabular}{lcccccc}
\hline Lag & LogL & LR & FPE & AIC & SC & HQ \\
\hline 0 & -2427.81 & NA & 3.24 & 65.85 & 66.14 & 65.97 \\
1 & -1898.92 & 914.82 & $1.82^{*}$ & 53.75 & $56.55^{*}$ & $54.87^{*}$ \\
2 & -1824.27 & 110.96 & 2.36 & 53.92 & 59.25 & 56.05 \\
3 & -1726.35 & $121.73^{*}$ & 1.92 & 53.46 & 61.31 & 56.59 \\
4 & -1631.37 & 94.986 & 2.24 & $53.09^{*}$ & 63.45 & 57.22 \\
\hline
\end{tabular}

Note. *indicates the selected optimum lag order by using the criterion; LR: Sequential modified LR test statistics (each test at 5\% level); FPE: Final prediction error. AIC: Akaike information criterion; SC: Schwarz information criterion; HQ: Hannan-Quinn information criterion.

To apply the lag order criterion, the study formulated VAR model for the banking index and selected macroeconomic variables. Later on, lag order criterion was employed on the results of VAR model. In lag order criterion, the study used four lag orders to investigate the optimum lag order out of them. The reason for not selecting higher lag order is because the numbers of observations in the study are 78 and with such observations, it was better to have the smaller lag order for better results.

The study utilized Akaike information criterion (AIC), Schwarz information criterion(SC) and Hannan-Quinn information criterion (HQ) for the selection of optimum lag order for study. SC and HQ suggested lag order 1 to be the optimum lag order for study. As two criterions suggested one lag order so the study selected one lag order to investigate the long run association between banking index and selected macroeconomic variables.

There are different statistical techniques which could be employed to investigate the long run association between selected macroeconomic series and banking index. Every statistical tool which could be used for such purpose has its assumptions. To investigate the long run association between selected macroeconomic series and banking index, the study can employ Johansen's Co integration test. To apply this test on the selected macroeconomic series and banking index, all of the time series should be integrated at same level. The ADF test provided evidence that the selected time series are not integrated at a same level. The PP test justified the results of $\mathrm{ADF}$ test by providing similar results that selected time series are not integrated at the same level. This implies that Johansen's cointegration test cannot be applied on all of the selected macroeconomic series and banking indexes. To apply Johansen's cointegration test, the study will be required to test only those time series which are integrated at same level but this application is not possible because of the fact that banking index which is the dependent variable in study is integrated at $\mathrm{I}(0)$ and most of the time series of macroeconomic variables are integrated at I(1).

Another statistical technique which can be used to investigate a long run association between selected macroeconomic series and banking index is ARDL approach. This approach is used for time series data which is integrated at different levels. The ADF test and PP test provided information that selected macroeconomic series and banking index are integrated at different levels. Thus, ARDL approach is suitable for application under these constraints. The ARDL approach to investigate long run association provides an edge over Johansen's cointegration technique because ARDL can be applied even if the variables are found to be co integrated at different levels. One of the primary assumptions of ARDL approach to long run association requires that none of the time series under study is integrated at I(2). The test results of ADF and PP justifies that none of the time series is embedded at $\mathrm{I}(2)$ when intercept and constant both are included in the study. The data meets the assumptions of ARDL approach due to which this approach has been employed to test the long run association between selected macroeconomic series and banking index.

There are different significant advantages of using ARDL approach to investigate a long run association between selected macroeconomic series and banking index in this study. The primary advantage is that ARDL approach is suitable for application on relatively small sample size. The results obtained by application of ARLD approach on relatively small sample size provides better results as compare to other statistical techniques used for testing long run association. This study covered seven years of data for selected macroeconomic series and banking index ranging January 2008 to August 2014. Due to limited data availability for selected macro series and banking index, the selection of ARDL is once again suited to the constraints. Thus, the limitations in the study directed towards usage of ARDL approach to investigate the long run association between selected macroeconomic series and banking index. 
The study utilized 1 lag order to formulate the ARDL model to investigate the long run co-movement between banking index and selected macroeconomic variables. The ARDL model formulated under 1 lag order is as follows:

$$
\begin{aligned}
& \text { (LnIND) LnIND (t-1) LnBOND(t-1) LnEXRUS(t-1) LnEXP }(\mathrm{t}-1) \operatorname{LnINF}(\mathrm{t}-1) \operatorname{LnIP}(\mathrm{t}-1) \operatorname{LnKIBOR}(\mathrm{t}-1) \\
& \operatorname{LnMONEY}(\mathrm{t}-1) \operatorname{LnOIL}(\mathrm{t}-1) \Delta(\operatorname{LnIND}(\mathrm{t}-1)) \Delta(\operatorname{LnBOND}(\mathrm{t}-1)) \Delta(\operatorname{LnEXRUS}(\mathrm{t}-1)) \Delta(\operatorname{LnEXP}(\mathrm{t}-1)) \\
& \Delta(\operatorname{LnINF}(\mathrm{t}-1)) \Delta(\operatorname{LnIP}(\mathrm{t}-1)) \Delta(\operatorname{LnKIBOR}(\mathrm{t}-1)) \Delta(\operatorname{LnMONEY}(\mathrm{t}-1)) \Delta(\operatorname{LnOIL}(\mathrm{t}-1)) \mathrm{c} @ \text { trend }
\end{aligned}
$$

The Figure 2 depicts the movement of banking index and selected macroeconomic variables by taking their log for ARDL testing purpose at the end. Time Series of Banking Sector Index and Macroeconomic Variables (In Lag form) According to ADF test applied, industrial production was stationary with the inclusion of both intercept and trend. Due to this reason, the ARDL model formulated in this study using one lag order included intercept and trend both in the equation. The OLS method was utilized to test the formulated ARDL model in this study. The results obtained by ARDL 1 lag order model are shown on the following page:

Table 5. Auto-regressive distributed lag result

\begin{tabular}{llll}
\hline Variable & Coefficient & t-Statistics & Prob. \\
\hline LnINDEX(t-1) & -1.001 & -5.99 & 0.00 \\
LnBOND(t-1) & 0.008 & 0.43 & 0.66 \\
LnEXCHANGE(t-1) & -0.039 & -1.85 & 0.07 \\
LnEXPORTS(t-1) & 0.007 & 0.90 & 0.36 \\
LnINFLATION(t-1) & -0.010 & -1.96 & 0.05 \\
LnIP(t-1) & 0.002 & 0.28 & 0.77 \\
LnKIBOR(t-1) & 0.004 & 0.57 & 0.56 \\
LnMONEY(t-1) & -0.008 & -0.24 & 0.81 \\
LnOIL(t-1) & -0.019 & -3.07 & 0.00 \\
$\Delta$ LnINDEX(t-1) & 0.219 & 1.79 & 0.07 \\
$\Delta$ LnBOND(t-1) & 0.012 & 0.67 & 0.50 \\
$\Delta$ LnEXCHANGE(t-1) & -0.004 & -0.07 & 0.94 \\
$\Delta$ LnEXPORTS(t-1) & 0.004 & 0.42 & 0.67 \\
$\Delta$ LnINFLATION(t-1) & 0.012 & 1.85 & 0.06 \\
$\Delta$ LnIP(t-1) & 0.006 & 0.51 & 0.61 \\
$\Delta$ LnKIBOR(t-1) & -0.003 & -0.22 & 0.82 \\
$\Delta$ LnMONEY(t-1) & 0.000 & -0.00 & 0.99 \\
$\Delta$ LnOIL(t-1) & 0.006 & 0.66 & 0.51 \\
C & 7.132 & 5.67 & 0.00 \\
@ TREND & 0.000 & 0.78 & 0.43 \\
\hline R-squared & 0.59 & F-statistic & 4.36 \\
Durbin-Watson stat & 2.13 & Prob(F-statistic) & 0.00 \\
\hline
\end{tabular}

The probability values for exchange rate, inflation, and oil prices are less than $10 \%$ significance level due to which the null hypothesis for the exchange rate, inflation, and oil prices have been rejected. The alternative hypothesis for the exchange rate, inflation, and oil prices has been accepted suggesting that there prevails long run relationship between banking sector index and macroeconomic variables exchange rate, inflation and oil prices. The probability values for a macroeconomic variables interest rate on bonds, exports, industrial production, KIBOR and money supply are more than $10 \%$ significance level due to which the research fails to reject the null hypothesis for these variables. The alternative hypothesis has been rejected for an interest rate on bonds, exports, industrial production, KIBOR and money supply suggesting that there does not prevail long run relationship between these variables and banking sector index. The Probability value of F-Statistics suggests that the model is significant and can be opted for study. The probability value suggests that model selected for ARDL is a good fit model. The Durbin-Watson (DW) test is employed to identify the presence of autocorrelation in the selected model. The acceptable value of DW statistics test lies in a range of 1.75 to 2.25 . The results suggest that the value of DW statistics for selected ARDL model is 2.14, which is within a range of acceptance. Thus, the assumption of autocorrelation has been satisfied. There is a presence of a slight negative autocorrelation in selected ARDL model which is within the acceptable range. To investigate the long run association between selected macroeconomic variables and banking index, the study applied bound testing on the results obtained from ARDL model under one lag order. Bound testing was also used by Shahbaz, Ahmed and Ali (2008) to 
investigate long run co integration between stock market development and economic growth in pakistan. The results of bound testing applied on ARDL model is as follows:

Table 6. Wald-Coefficient restrictions test result

\begin{tabular}{clll}
\hline Wald-Coefficient Restrictions Test & & \\
\hline F-statistic & 5.31 & Probability $(9,56)$ & 0.00 \\
Chi-square & 47.87 & Probability $(9)$ & 0.00 \\
\hline Null Hypothesis: $\mathrm{C}(1)=\mathrm{C}(2)=\mathrm{C}(3)=\mathrm{C}(4)=\mathrm{C}(5)=\mathrm{C}(6)=\mathrm{C}(7)=\mathrm{C}(8)=\mathrm{C}(9)=0$ & \\
\hline
\end{tabular}

Bounding test for ARDL model of cointegration has been employed to investigate the long run association between selected macroeconomic variables and banking index. The null hypothesis and alternative hypothesis of bound testing used in this study are shown below:

$$
\begin{aligned}
& \mathrm{H} 0: \mathrm{C}(1)=\mathrm{C}(2)=\mathrm{C}(3)=\mathrm{C}(4)=\mathrm{C}(5)=\mathrm{C}(6)=\mathrm{C}(7)=\mathrm{C}(8)=\mathrm{C}(9)=0 \\
& \mathrm{H} 1: \mathrm{C}(i) \neq 0, \text { for any } i, i=1,2, \ldots, 9
\end{aligned}
$$

The null hypothesis of bound testing states that there is no long-run cointegration between selected macroeconomic variables and banking index while alternative hypothesis of Bound testing states that there is long run cointegration between selected macroeconomic variables and banking index. Thus, the null hypothesis of no cointegration has been tested against the alternative hypothesis of cointegration. To interpret the F-Statistics value, the study will need upper bound and lower bound values for F-Statistics at 1\%, 5\%, and 10\% significance level. Thus, the upper bound and lower bound values for F-Statistics are shown as follows:

Table 7. Bound testing for ARDL model of cointegration

\begin{tabular}{lcc}
\hline F-statistic $=5.31$ & & \\
\hline Significance Level & Lower Bound Value & Upper Bound Value \\
\hline $10 \%$ & 2.29 & 3.38 \\
$5 \%$ & 2.60 & 3.74 \\
$1 \%$ & 3.22 & 4.41 \\
\hline
\end{tabular}

The above table contains that lower bound values and upper bound values for bound testing at $1 \%, 5 \%$, and $10 \%$ significance level. If the F-Statistics of bound testing is greater than lower bound value and upper bound value, then null hypothesis of no cointegration between selected macroeconomic variables and banking index can be rejected. The F-Statistics of bound testing for ARDL is greater than the limits of lower bound value and upper bound value due to which the null hypothesis is rejected. Hence, bound testing suggests that there is a presence of long-run cointegration or association between selected macroeconomic variables and banking index. The probability value is also less than $1 \%, 5 \%$ and $10 \%$ suggesting rejection of null hypothesis in this study the presence of the long run association between selected macroeconomic variables and banking index indicates that there might be a presence of unidirectional or bidirectional causality as well. To investigate bidirectional causality between selected macroeconomic variables and banking index, the study employed Granger Causality test. The Granger causality test investigated the bidirectional and unidirectional causality between selected macroeconomic variables and banking index. The results of Granger causality test described the Granger causal relation between selected macroeconomic variables and banking index. After employing lag order selection criterion, the optimal lag order selected was one lag order. Thus, Granger causality test was applied at one lag order. Granger Causality test was used at first difference level for the selected macroeconomic variables and banking index to make sure that all the variables are stationary. The results obtained from the Granger causality test are shown on following page:

Table 8. Pairwise Granger causality tests at Lag 1

\begin{tabular}{lccc}
\hline Null Hypothesis: & Obs & F-Statistic & Prob. \\
\hline DINDEX does not Granger Cause DBOND & 76 & 6.63 & $0.01^{* *}$ \\
DKIBOR does not Granger Cause DINDEX & 76 & 6.41 & $0.01^{* *}$ \\
DOIL does not Granger Cause DINDEX & 76 & 12.63 & $0.00^{* * *}$ \\
\hline
\end{tabular}

Note. *Variable is significant at .10(10\%) significance level; **Variable is significant at .05(5\%) significance level; ***Variable is significant at .01(1\%) significance level. 
The results of Granger Causality provide information for bivariate unidirectional and bidirectional causality between selected macroeconomic variables and banking index. From the results of Granger Causality, the research found that banking index does Granger causes government bonds yield rate in a unidirectional manner at 5\% significance level. The KIBOR also Granger causes banking index in a unidirectional manner at 5\% significance level. The Granger Causality between banking index and Oil prices is also unidirectional from oil prices to banking index which means oil prices Granger causes banking index at $1 \%$ significance level. Thus, Granger causality test indicates unidirectional Granger causality from macroeconomic indicators KIBOR and oil prices to banking index. The Granger causality test also indicates unidirectional Granger causality from banking index to government bonds yield rate.

\section{Conclusion}

After presenting The macroeconomic variables included in the study are CPI as measure of inflation, Exchange rate (With U.S), Oil Prices, Exports Volume, Pakistan Government Bond Yield 10 year rate as a proxy for long-term interest rate, KIBOR as a proxy for short-term interest rate, Industrial Production and Money Supply (M0). Long run association and bidirectional causality of these selected macroeconomic variables were investigated with banking index in Pakistan for the banks listed at KSE. The timeline of the study was from January 2008 to August 2014. The study was focused towards the examination of long-term association between selected macroeconomic indicators and banking index in Pakistan. For this purpose, the study employed ARDL technique as the selected macroeconomic indicators and banking index were integrated at the different level suggested by ADF and PP test. The results of ARDL technique used in this study provided evidence that there exists long-term association between macroeconomic indicators exchange rate, inflation, oil prices, and banking index in Pakistan. Thus, the pattern of selected macroeconomic variables can be used for predicting the future performance of banking index in Pakistan. To investigate the bidirectional causality between selected macroeconomic variables and banking index in Pakistan, Granger causality technique was employed. The Granger causality technique tested the unidirectional and bidirectional Granger causality between selected macroeconomic variables and banking index in Pakistan. Under the selected one lag order, the study employed Granger causality test. The Granger causality test provides evidence for the existence of unidirectional Granger causality from banking index to Government bond yield ten-year rate. The results of Granger causality also suggests that Oil prices and KIBOR Granger cause banking index in Pakistan. The Granger causality also suggested that banking index in Pakistan is a leading indicator in case of Government bond yield ten-year rate while it is lagging indicator in case of oil prices and KIBOR. Thus, the leading and lagging behavior of banking index in Pakistan was also tested by using Granger causality technique.

\section{Limitation of Study}

There are a total of 25 banks listed at KSE in the banking sector of Pakistan. Some of these banks have been recently formed in past five years due to which the data for the stocks of these recently formulated banks is not available at KSE website. Due to the limitation of data, the study used those banks which have been listed at KSE since 2007. There is total of 487 items in the basket of CPI which are used for its calculation by PBS. The monthly bulletins of PBS do not state that these 487 items were not changed over time. So, it is possible that during the calculation of CPI, the list of items may have been changed to reduce the inflation rate or adjust it due to political factor. So, it was not possible to make sure that the list of items used for CPI calculation remains same. The reliable sources in Pakistan do have data for industrial production, and the study used data for industrial production in units from the database of World Bank for Pakistan. The World Bank has not operationalized the industrial production data for Pakistan, so the study was not able to provide the items which have been included in the calculation of industrial production in Pakistan by World Bank. The timeline of the study was from January 2008 to August 2014 which formulates a total of 80 months. The study included 78 months during this period excluding October and November of 2008. The reason for excluding these two months was that for most of the banks listed at KSE, stock prices for these two months of 2008 were not present. Stock prices for few banks listed at KSE were available. Due to limited Stock prices, the total market capitalization for these two months showed abnormal differences as compare to preceding and following months. That is why some included and tested months were 78 from January 2008 to August 2014. The study was not able to extend its timeline due to stock prices for most of the banks were not available at KSE website before 2008 .

\section{Acknowledgements}

TENG Jian-Zhou Acknowledges Financial support from the China's National Social Science research grant (16BTJ025). 


\section{References}

Adam, A. M., \& Tweneboah, G. (2008). Macroeconomic Factors and Stock Market Movement: Evidence from Ghana. Social Science Electronic Publishing. https://doi.org/10.2139/ssrn.1289842

Ahmad, A. (2009). A Comparative Study of Islamic Banking in Pakistan: Proposing and Testing a Model. Foundation University, Management Sciences. Islamabad: Foundation University.

Ahmed, S. (2011). Are Chinese Exports Sensitive to Changes in the Exchange Rate? DIANE Publishing, 2011.

Akmal, M. S. (2007). Stock Returns and Inflation: An Ardl Econometric Investigation Utilizing Pakistani Data. Pakistan Economic and Social Review, 45(01), 89-105.

Ali, A. (2008). Pakistan \& Gulf Economist (Vol. 27). The University of Michigan.

Ali, I., Rehman, K. U., Yilmaz, A. K., Khan, M. A., \& Afzal, H. (2010). Causal relationship between macro-economic indicators and stock exchange prices in Pakistan. African Journal of Business Management, 4(3), 312-319.

Ali, M. B. (2011). Impact of Micro and Macroeconomic Variables on Emerging Stock Market Return: A Case on Dhaka Stock Exchange (DSE). Interdisciplinary Journal of Research in Business, 1(05), 08-16.

Ali, P. I., \& Akujuobi. (2014). Empirical Analysis of the Relationship between Stock Market Returns and Macroeconomic Indicators in Nigeria. Research Journal of Finance and Accounting, 5(14), 34-40.

Al-Majali, A. A., \& Al-Assaf, G. I. (2014). Long-Run and Short-Run Relationship Between Stock Market Index and Main Macroeconomic Variables Performance in Jordan. European Scientific Journal, 10(10), 156-171.

Andrus, J. R., \& Mohammed, A. F. (1966). Trade, Finance, and Development in Pakistan. Stanford University Press.

Arora. (2014). Indian Economic Development For Class Xi. Tata McGraw-Hill Education.

Attari, M. I., \& Safdar, L. (2013). The Relationship between Macroeconomic Volatility and the Stock Market Volatility: Empirical Evidence from Pakistan. Pakistan Journal of Commerce and Social Sciences, 7(2), 309-320.

Babatunde, M. A., Adenikinju, O., \& Adenikinju, A. F. (2013). Oil price shocks and stock market behaviour in Nigeria. Journal of Economic Studies, 40(02), 180-202. https://doi.org/10.1108/01443581311283664

Banerjee, B. (2015). Fundamentals of Financial Management. PHI Learning Pvt. Ltd.

Beltratti, A., \& Morana, C. (2006). Breaks and persistency: macroeconomic causes of stock market volatility. Journal of Econometrics, 131(1-2), 151-177. https://doi.org/10.1016/j.jeconom.2005.01.007

Bikker, J. A., \& Hu, H. (2002). Cyclical Patterns in Profits, Provisioning and Lending of Banks. Amsterdam: De Nederlandsche Bank NV.

Blanchard, O., \& Sheen, J. (2013). Macroeconomics; Australasian Edition. Pearson Higher Education AU.

Bodie, Z. (1976). Common Stocks as a Hedge Against Inflation. The Journal of Finance, 31(02), 459-470. https://doi.org/10.1111/j.1540-6261.1976.tb01899.x

Boyes, W., \& Melvin, M. (2015). Economics. Cengage Learning, 01-Jan-2015.

Buechner, M. N. (2011). Objective Economics: How Ayn Rand's Philosophy Changes Everything about Economics. Rowman \& Littlefield.

De Vita, G., \& Abbott, A. (2004). Real exchange rate volatility and US exports: an ARDL bounds testing approach. Economic Issues, 9(1), 69-78.

Denzin, N. K., \& Giardina, M. D. (2011). Qualitative Inquiry and Global Crises. Left Coast Press.

Downward, P., \& Dawson, A. (2002). The Economics of Professional Team Sports. Routledge.

Elliott, J. A., \& Sundem, D. G. (2008). Introduction to Financial Accounting. Pearson Education India, 01-Sep-2008.

Erdem, C., Arslan, C. K., \& Erdem, M. S. (2005). Effects of macroeconomic variables on Istanbul stock exchange indexes. Applied Financial Economics, 15(14), 987-994. https://doi.org/10.1080/09603100500120365

Farhan, M., Sattar, A., Chaudhry, A. H., \& Khalil, F. (2012). Economic Determinants of Non-Performing Loans: Perception of Pakistani Bankers. European Journal of Business and Management, 87-99. 
Farooq, M. T., Keung, W. W., \& Kazmi, A. A. (2004). Linkage between Stock Market Prices and Exchange Rate: A Causality Analysis for Pakistan. The Pakistan Development Review, 639-649.

Fazal, H. (2006). Stock Prices, Real Sector and the Causal Analysis: The Case of Pakistan. Journal of Management and Social Sciences, 2(02), 179-185.

Florin, E. (2010). Causality Measures Between Neural Signals from Invasively and Non-invasively Obtained Local Field Potentials in Humans. Forschungszentrum Jülich.

Frank, S. (2006). Money and the Stock Market: What is the Relation? Retrieved from http://mises.org/daily/2296/Money-and-the-Stock-Market-What-is-the-Relation

Galderisi, P. (2015). Understanding Political Science Statistics: Observations and Expectations in Political Analysis. Routledge.

Gan, C., Lee, M., Yong, H. H., \& Zhang, J. (2006). Macroeconomic Variables and Stock Market Interactions: New Zealand Evidence. Investment Management and Financial Innovations, 3(04), 89-101.

Gay, R. D. (2008). Effect Of Macroeconomic Variables On Stock Market Returns For Four Emerging Economies: Brazil, Russia, India, And China. International Business \& Economics Research Journal, 7(03).

Gjerde, Ø., \& Sættem, F. (1999). Causal relations among stock returns and macroeconomic variables in a small, open economy. Journal of International Financial Markets, Institutions and Money, 9(01), 61-74. https://doi.org/10.1016/S1042-4431(98)00036-5

Granger, C. W. (1969). Investigating Causal Relations by Econometric Models and Cross-spectral Methods. Econometrica, 37(03), 424-438. https://doi.org/10.2307/1912791

Granger, C. W., Huang, B. N., \& Yang, C. W. (2000). A Bivariate Causality between Stock Prices and Exchange Rates: Evidence from Recent Asia Flu. University of California.

Haider, J. (2013). An Analytical Study of Relationship of Macroeconomic Indicators on Movement of KSE (Karachi Stock Exchange) Prices. Journal of Global Economy.

Hall, R., \& Lieberman, M. (2012). Macroeconomics: Principles and Applications. Cengage Learning.

Hamori, S. (2012). An Empirical Investigation of Stock Markets: The CCF Approach. Springer Science \& Business Media, 06-Dec-2012.

Hansen, N. J. H., \& Sulla, O. (2013). Credit Growth in Latin America: Financial Development or Credit Boom? International Monetary Fund.

Hasan, A., \& Javed, M. T. (2009). An Empirical Investigation of the Causal Relationship among Monetary Variables and Equity Market Returns. The Lahore Journal of Economics, 115-137.

Herve, D. B., Chanmalai, B., \& Shen, Y. (2011). The Study of Causal Relationship between Stock Market Indices and Macroeconomic Variables in Cote d'Ivoire: Evidence from Error-Correction Models and Granger Causality Test. International Journal of Business and Management, 6(12), 146-169. https://doi.org/10.5539/ijbm.v6n12p146

Humpe, A., \& Macmillan, P. (2009). Can macroeconomic variables explain long-term stock market movements? A comparison of the US and Japan. Applied Financial Economics, 19(2), 111-119. https://doi.org/10.1080/09603100701748956

Husain, F., \& Mahmood, T. (2001). The Stock Market and the Economy in Pakistan. The Pakistan Development Review, 107-114.

Husain, I. (2011). Prospects and Challenges for Increasing India-Pakistan Trade. Washington: Atlantic Council.

Ibrahim, M. H., \& Yusoff, S. W. (2001). Macroeconomic Variables, Exchange Rate and Stock Price: A Malaysian Perspective. International Journal of Economics, Management and Accounting, 9(2), 141-163.

IMF. (2014). List of LIC DSAs for PRGT-Eligible Countries. IMF.

International Monetary Fund. (2010). Pakistan: Poverty Reduction Strategy Paper. International Monetary Fund, 06-Jul-2010.

Issahaku, H., Ustarz, Y., \& Domanban, P. B. (2013). Macro-economic Variables and Stock Market Returns in Ghana: Any Causal Link. Asian Economic and Financial Review, 3(8), 1044-1062.

Jaffe, J. F., \& Mandelker, G. (1976). The Value of the Firm under Regulation. The Journal of Finance, 31(2), 701-713. https://doi.org/10.1111/j.1540-6261.1976.tb01915.x 
Johansen, S., \& Juselius, K. (1990). Maximum Likelihood Estimation and Inference on Cointegration - With Applications to the Demand for Money. Oxford Bulletin of Economics and Statistics, 52(2), 169-210. https://doi.org/10.1111/j.1468-0084.1990.mp52002003.x

Wang, Q., \& Fasano-Filho, U. (2002). Testing the Relationship Between Government Spending and Revenue: Evidence From GCC Countries. International Monetary Fund.

Were, M., \& Wambua, J. (2014). What factors drive interest rate spread of commercial banks? Empirical evidence from Kenya. Review of Development Finance, 73-82.

Wiener, N. (1956). The theory of prediction. Modern mathematics for engineers, 1, 125-139.

Wongbangpo, P., \& Sharma, S. C. (2002). Stock market and macroeconomic fundamental Dynamic interactions: ASEAN-5 countries. Journal of Asian Economics, 13(1), 27-51. https://doi.org/10.1016/S1049-0078(01)00111-7

World Scientific. (2007). Quantitative Analysis, Derivatives Modeling, and Trading Strategies: Theory and Applications of Derivatives Modeling. World Scientific.

Xu, J., Fry, J. A., Lev, B., \& Hajiyev, A. (2013). Proceedings of the Seventh International Conference on Management Science and Engineering Management: Focused on Electrical and Information Technology (Vol. 2). Springer Science \& Business Media.

\section{Copyrights}

Copyright for this article is retained by the author(s), with first publication rights granted to the journal.

This is an open-access article distributed under the terms and conditions of the Creative Commons Attribution license (http://creativecommons.org/licenses/by/4.0/). 